\title{
ROBERTSON SCOTT AND THE COUNTRYMAN Neil Philip
}

(Edited version of a paper given to the Idbury Literary Festival, 2005)

Idbury, a small village in west Oxfordshire, is one of 47 English villages listed in K. M. Briggs, A Dictionary of British Folk-Tales as 'Places supposed to be inhabited by simpletons'. When J.W. Robertson Scott came to live there in 1923 it was a run-down, fairly unremarkable place. It was a village in decline - down from 113 residents in 1851 to just 41. The first thing Scott did when he retired to Idbury was to write a book called The Dying Peasant. Yet within a decade the village was a thriving place, with 8 new council houses built on land acquired and donated by Scott, and a new sense of pride and purpose in village life, from the children who were chosen as 'parish marshalls' and charged with keeping the village tidy to the adults who suddenly found their knowledge valued and their opinions listened to. It was a remarkable transformation, and although Robertson Scott may seem now rather paternalistic in his attitude to the villagers, at the time his willingness to mix with them on equal terms was really extraordinary, and was I think the mainspring for the village's revival.

This improvement of the village - the picturesque houses are in a very bad state, let's find the land and the money to build some new ones - was a typical piece of practical philanthropy from Scott. It is interesting too that he made sure the cottages had plenty of garden to grow vegetables, or keep a pig; in fact village lore has it that he had to be restrained from making the very substantial gardens twice as big again. 


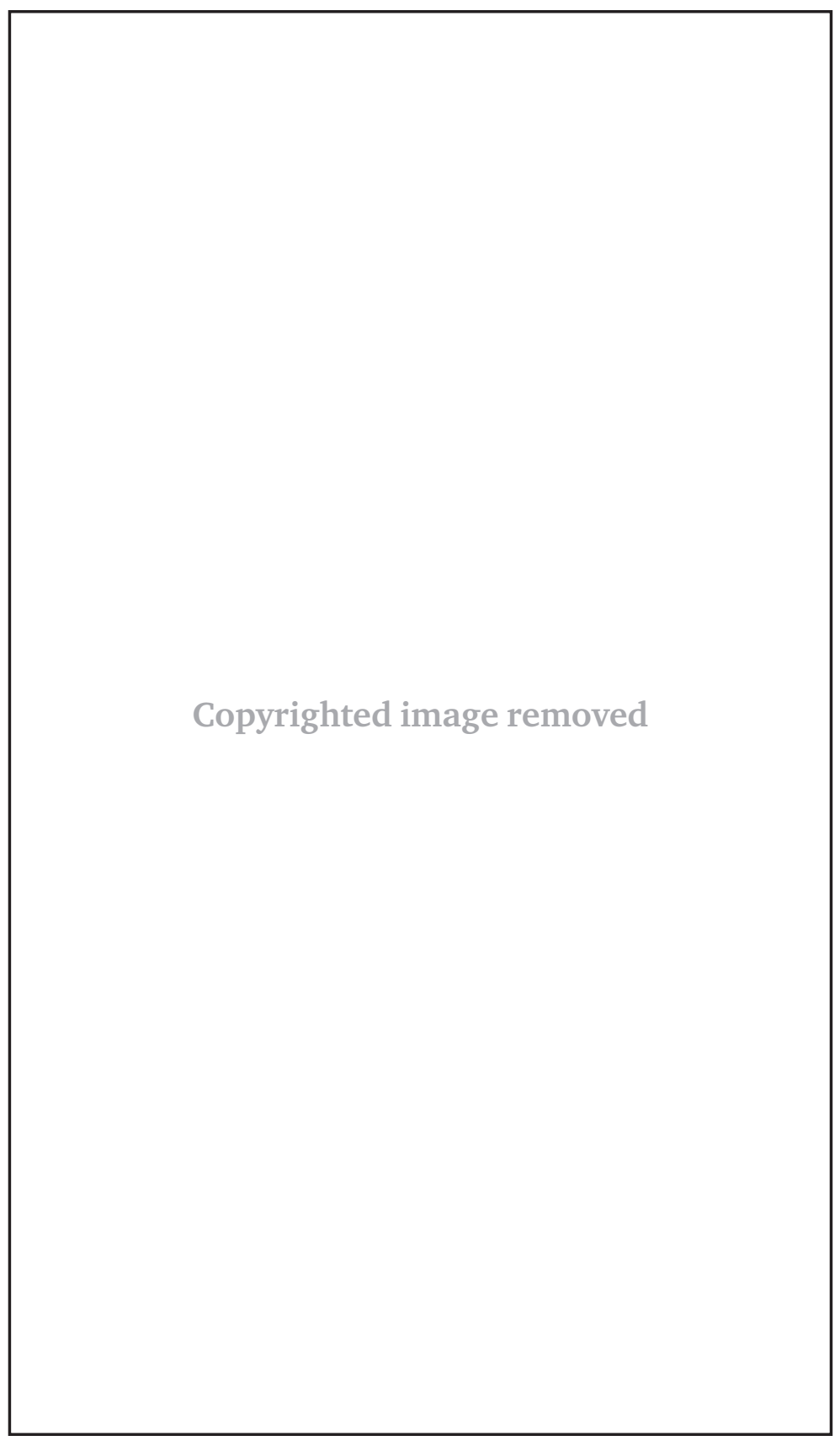

John and Elspet Robertson Scott at Idbury Manor in the late 1920s 
The profound effect that Robertson Scott had on Idbury can be seen by the way the village responded to the General Election of 1923. The local Liberal candidate was the cricketer C. B. Fry. Next to Fry's combined Christmas card and election leaflet in the Robertson Scott visitors' book, known as the Idbury Book, is a note in Robertson Scott's hand: 'The whole hamlet voted Red (i.e. Liberal) except the Minchins! Butt (farmer) did not vote (Plymouth Brother).' Underneath this is a typescript rhyme, with Scott's note that 'The children walked up and down singing it on Election Day':

We don't want your old Protection.

Free trade beats it every time.

If you vote for C. B. Fry

Cheaper food you'll surely buy.

That's why Idbury is wearing red to-day.

Scott's influence was not purely local. Other villages looked to Idbury as a source of inspiration. In his brilliant book about Tyneham in Dorset, The Village That Died for England, Patrick Wright writes about the village of East Chaldon, home to the writers T. F. Powys, Valentine Ackland, and Sylvia Townsend Warner. Warner's frankly Marxist political views about the English rural economy were influenced, he says, by the series of anti-idyllic articles printed in The Nation under the title 'England's Green and Pleasant Land', and published in book form in 1925. The anonymous author of these hard-hitting polemics was J. W. Robertson Scott. It was from Scott, he writes, 'that Townsend Warner had first grasped how much a programme of educational and cultural activities could do to enliven a demoralised village. Idbury had been "a melancholy little hamlet, full of picturesque cottages that had gone bad". But Robertson Scott, who was well aware of the need to cut through the "prettyish seeming" of country life as perceived by "the week-ending classes" and to address the "haggard reality" underneath, was taking steps to revitalise the place.'

Prominent among these steps was the series of Sunday afternoon talks and events held in the school house under the 
title Village Neighbours, after the inscription on the treble bell in Idbury Church, 'Peace and Good Neighbourhood'. These were of a very varied nature. Edith Evans performed the death of Socrates; a string quartet played chamber music; a skilled upholsterer showed what could be done with a wornout chair. The aptly named Miss D. B. Grime of Ruskin College, Oxford, spoke on 'My Life in a Cotton Mill'; Mr Robert Hobbs of Kelmscott spoke on 'Famous Farmers', other lecturers included Frances, the Countess of Warwick, Sylvia Townsend Warner and, on at least two occasions, George Bernard Shaw.

Another important change to village life encouraged and possibly arranged by Scott was the arrival of radio in Idbury and Fifield in 1926, with the coming of the telegraph. Robertson Scott was an early and regular broadcaster on the $\mathrm{BBC}$ on country matters, and saw at once the enormous potential for education and cultural enrichment that radio offered to those in the country. Scott wrote an article for The Radio Times of April 23rd, 1926, entitled 'New Life for the Village', extolling the benefits of the wireless and illustrated with a photo of William Paxford and William Soden (the blacksmith) listening to the radio on enormous headphones. There is also a plan of Fifield showing which houses have wireless installations - 16 out of 41 .

So who was J. W. Robertson Scott?

He was of Scottish parentage, but born and brought up in Wigton in Cumbria. He was born on April 20th, 1866, and by the time he moved into Idbury Manor in early 1923 was already 56 years old, and was retiring from the hurly-burly of a distinguished journalistic career. He learned his trade under W. T. Stead, the pioneering editor of the Pall Mall Gazette, and subsequently wrote for a number of liberal and progressive papers, including the Westminster Gazette and the Daily Chronicle, from which he resigned in 1899 as a mark of his opposition to the Boer War. He went to live in Essex and transformed himself into an expert on rural and agricultural topics. In 1906 he met Elspet Keith, a fellow-contributor to the magazine The World's Work, and they were married for 50 years until her death in 1956; they had no children of their 
own, but one adopted son, Peter, who was killed in the Second World War.

Robertson Scott was a pacifist, and he and Elspet spent the years $1914-18$ in Japan. They returned to England after the war, and he took a post on The Nation (which later amalgamated with The New Statesman), from which he retired in 1922 to Idbury Manor, which he described as 'a high cold house on the edge of a hamlet'. He also made the rather rash decision for a man in his 60 s to found a new magazine, The Countryman, which he would edit and publish himself from his home in Idbury. The first issue came out in Spring 1927, with a print run of 9000 copies, many of which were given away. Within seven years the magazine was selling 9000 copies of each issue,

Scott made a very unlikely rural squire - he was a radical in every sense: a vegetarian, a feminist, a freethinker, a pacificist, a teetotaller, a fierce opponent of hunting and other cruel sports, and a believer in what he called 'rural advance', through education and social improvement. As Victor Bonham-Carter who worked for him at The Countryman, writes, 'Not surprisingly he was much disliked in the neighbourhood'. He did have a few like-minded friends locally, of whom the most notable was probably the distinguished socialist Sir Stafford Cripps at Filkins (whose son John Cripps would become the second editor of The Countryman), but Scott was definitely resented by the rural hierarchy of the day.

Robertson Scott wrote an account of the founding and running of The Countryman, in his book about newspaper editors he had known, 'We' and $M e$, the frontispiece to which is a photo showing Mr and Mrs Scott in their attic office; Anton van Anrooy's original drawing of the fiddle player of the Idbury morris side, Charles Benfield - the frontispiece of the first issue of the magazine - is hanging on the wall. Scott received a lot of discouragement from fellow professionals, but trusting his own experience and his wife's instincts he launched the magazine anyway. The first issue in April 1927 had 82 editorial pages and 16 pages of adverts - even though Scott resolutely refused to accept adverts for alcoholic drinks, 
patent medicines, circuses, betting, and a whole list of other things of which he disapproved.

Scott proudly claimed among his readers such luminaries as Princess Louise, the Duchess of Argyll, Earl Attlee, the sexologist Havelock Ellis, George Bernard Shaw, H. G. Wells, Rudyard Kipling, Lord and Lady Baden-Powell and D. H. Lawrence. To please such a disparate readership, the magazine itself had to be both varied and lively. Thomas Hardy wrote, 'The Countryman makes one feel in the country'; Bernard Shaw that 'I take in many magazines I never read, but I always read The Countryman'.

The staff were overworked and underpaid, and behind the Scotts' paternalistic facade was a ruthless streak. Despite the family-style tea parties "with raspberries and lashings of cream, baps, and chocolate cakes', and the fun and games, such as summer evenings when Robertson Scott threw pennies into the murky spring-fed swimming pool for the staff to dive for, there was a good deal of unhappiness. There was a very high turnover of staff, so that eventually, in Kathleen Wyborn's words, 'the Scotts were surrounded with an unwanted colony of ex-staff whom the current staff were forbidden to talk to. Of course we all did, which led to more sackings.' Bonham-Carter writes with great admiration of Robertson Scott as 'a first-class radical journalist' and 'an excellent teacher', but he also concludes that 'as an employer, he was a monster. He attracted young people into the country, eager to work for an "idealist" enterprise, willing to learn and willing to work for next to nothing while learning; but when they became useful, deserving proper pay, he sacked them and recruited fresh fools in their place.'

In Robertson Scott's visitor's book-cum-commonplace book from the 1920s, called The Idbury Book, is a line of music with the signature of the writer Sylvia Townsend Warner, dated 29 August - 28 September 1924. Townsend Warner was 31 , but her literary fame was still to come. She was staying in Idbury, in fact, to complete her first novel, still her best-known work, Lolly Willowes. She had rented a cottage from the Robertson Scotts - the Thatched Cottage, I believe. Certainly it could be Lolly's cottage in the book: 


\section{Copyrighted image removed}

Tea being done with, Laura took stock of her new domain. The parlour was furnished with a large mahogany table, four horsehair chairs and a horsehair sofa, an armchair, and a sideboard, rather gimcrack compared to the rest of the furniture. . . On either side of the hearth were cupboards, and the fireplace was of a cottage pattern with hobs, and a small oven on one side.

Lolly Willowes is the story of a spinster who finds her vocation as a witch. As she tells the Devil:

It's like this. When I think of witches I seem to see all over England, all over Europe, women living and growing old, as common as blackberries, and as unregarded. I see them, wives and sisters of respectable men, chapel members, and blacksmiths, and small farmers, and Puritans. In places like Bedfordshire, the sort of country one sees from the train. You know. Well, there they are, child-rearing, house-keeping, hanging washed dishcloths on currant bushes; and for diversion each other's silly conversation, and listening to men talking together in the way that men talk and women listen. Quite different to the way women talk, and men listen, if they listen at all. And all the time being thrust down into dullness when the one thing all women hate is to be thought dull.

At the time, Sylvia Townsend Warner was known as one of the editors of the 10-volume Tudor Church Music, and as an up-and-coming poet. She wrote a number of poems both in and about Idbury, including 'Country Thought':

Idbury bells are ringing,

And Westcote has just begun, 
And down in the valley

Ring the bells of Bledington.

To hear all these church bells

Ring-ringing together -

Chiming so pleasantly,

As if nothing were the matter -

The notion might come

To some religious thinker

That the Lord God Almighty

Is a travelling tinker,

Who sits retired

In some grassy shade,

With a pipe - a clay one -

And plies his trade,

A-tinkling and a-tinkering

To mend up the souls

That weekday wickedness

Has worn into holes:

And yet there is not

One Tinker, but Three -

One at Westcote, one at Bledington,

And one at Idbury.

The song the Idbury bells sing, by the way, is not 'ding dang dong' but, I am reliably informed, 'Hang Tom Bond'.

Townsend Warner's 'A Song About a Lamb' was written in Idbury, too, and I like to imagine it set in St. Nicholas Church, to which she would have looked across the green from the Thatched Cottage:

'O God, the Sure Defence

Of Jacob's race,

Lover of innocence

And a smooth face,

Accept my sacrifice -

A little lamb, bought at the market price. 
'With fleece so soft and clean

And horns not yet

A-bud, the creature's been

The children's pet.

And sore they wept to see

Their snub-nosed friend come trotting after me.'

God heard: the lightnings brake

Forth in his honour;

But by some slight mistake

Consumed the donor.

The lamb fell in a muse -

But soon took heart, and leaped among the pews.

Sylvia Townsend Warner's published diaries contain only two references to Robertson Scott, but they show that she remained on visiting terms with him in 1950. Her published letters contain just one from 'The Manor House, Idbury', on the 10th of November 1924, to the writer David Garnett, who had just made his name with the magical novella Lady Into Fox, set just two miles south at Tangley Hall.

The Idbury Book records Sylvia Townsend Warner's stay in Idbury on the same page as a visit from E. M. Forster, who inscribed his mantra from Howard's End, 'Only connect.' Other distinguished visitors to Idbury in the 1920s include the writers May Sinclair and E.V. Lucas; the folk song collectors Cecil Sharp, Maud Karpeles, and Margaret Shaw; the journalist C. P. Scott (editor of the Manchester Guardian, and no relation to Robertson Scott); the potter Bernard Leach and the Japanese poet and journalist Yanagita Kunio

One interesting visitor who came to Idbury in 1924 and 1925 was Rolf Gardiner, who brought his dance troop the Travelling Morrice from Cambridge to perform on the manor house lawn; another member of this revival morris side was Arthur Heffer, the bookseller. Gardiner was attracted to Idbury because ... the village forms a crucial link in the chain of transmission of the morris dance. He was an idealistic young man who, inspired by the wandervogel of post-war Germany, wanted to revive English culture through folk song and dance and healthy outdoor pursuits. At the time of his 
visits, he was a leading member of the Kibbo Kift Kindred, a grown-up offshoot of the Boy Scout movement, which wanted to revive folk life from beneath the deadening influence of 'Machine civilisation'. In North Dorset at Gore Farm he founded the Springhead Ring, a fellowship devoted to organic agriculture, organic living, and of course folk dancing, which still exists today as the Springhead Trust. But Gardiner's inspiration in the German youth movements of the 20 s were to enmesh him in fascism in the $30 \mathrm{~s}$, and he is now rather unfairly remembered as a Nazi sympathiser, who is supposed in folk legend to have saved the village of Fontmell Magna from Hitler's bombs by planting a swastika in the woods to warn away the German planes.

When Cecil Sharp and Maud Karpeles visited Idbury, staying overnight at the manor on the 10th of September 1923, they transcribed into the Idbury Book the jig 'Princess Royal' as whistled by Richard Bond, then aged 81, noting it as 'one of the Bledington-cum-Idbury morris airs'. Maud Karpeles records a remark made by $\mathrm{Mr}$ Bond on the 11th: 'Anybody that has a good ear can see by the tune what the steps are'.

Richard Bond was born in Fifield around 1842, and was an important source for Cecil Sharp when Sharp was brought to Bledington and Idbury by Reginald Tiddy before the First World War to record the Idbury-Bledington morris dances; 'Princess Royal' was one of 28 dances in the local repertoire, which, as recorded and published by Sharp in The Morris Book, has formed one of the principal roots of the English morris dance revival. The very first revival side, started by D'Arcy Ferris at Bidford in 1885, learned its dances from William Trotman, an Idbury man. Jonathan Harris of Bould lent Trotman a set of bells to get the enterprise going.

Idbury families such as Lainchbury, Paxford, Bond, Toms, and Harris were key members of the Idbury morris side, which by the time the tradition was recorded had merged with that of Bledington. Richard Bond told Cecil Sharp that, 'Both Idbury and Fifield had a morris side, but they danced exactly the same dances as the Bledington men, and to the same fiddler, Benfield' - that is, Charles Benfield of Bould. Earlier, the 
morris sides would have danced to a pipe and tabor. The morris dancers had rhymes as well as tunes and steps associated with the dances. A famous one collected from Idbury by Cecil Sharp is ' The Old Woman Tossed Up in a Blanket':

There was an old woman tossed up in a blanket Ninety-nine miles beyond the moon, And under one arm she carried a basket, And under t'other she carried a broom. Old woman, old woman, old woman cried I, Oh whither, oh whither, oh whither so high? I'm going to sweep cobwebs beyond the sky, And I'll be back with you by and by.

Another rhyme, recorded by M. K. Ashby in her history of Bledington, recalls Idbury's history of village lace-making which was often in the nineteenth century a pretext for discreet rural prostitution, there being nothing quite so enticing as a pretty girl sitting in a cottage doorway making lace. Ashby says that this quatrain, a parody of Greensleeves, is a fragment of the Idbury Mumming Play, though it may also have been associated with the morris:

Greensleeves and yellow lace,

Get up, you bitch, and work apace.

Your father lies in an awful place

All for the want of money.

In 1948 Scott edited a collection of articles from The Countryman under the title The Countryman Book. It includes a wide range of work, representative of the magazine itself, with contributions by H. E. Bates, T. F. Powys, Sylvia Townsend Warner, and M. K. Ashby, the historian of Bledington, to whose great book on her father, Joseph Ashby of Tysoe, Scott contributed a foreword.

In 1947 Robertson Scott decided to retire from editing The Countryman - which he had sold to the proprietors of Punch. The Scotts stayed in Idbury until the death of Elspet in 1956 after 50 years of marriage, and then of J. W. Robertson Scott at the age of 96 , in 1962. 